\title{
The hematological and clinical changes in rabbits exposed to powder of dried leaves of (Lantana camara) under experimental conditions
}

\author{
Nazar Jabbar Al-Khafaj Raad Mahmood Al-Zubaedi \\ Coll. of Vet. Med./ Univ. of Diyala - Iraq \\ email: Raad75m@gmail.com
}

(Received 15 September 2013, Accepted 18 November 2013 )

\begin{abstract}
The study was conducted on 10 local breed rabbits, $1-2$ years of age, and $1-1.5 \mathrm{~kg}$ body weight. Animals were divided into two equal groups. The first was the treated group which exposed to the dried powder of Lantana camara leaves mixed with the food at a dose rate of 5 g/ animal / day for three weeks, while the second group left without treatment as a control group. Clinically the study was revealed that the body temperature and body weight did not show any changes during the experiment, while the respiratory and heart rate were increased. Hematologically the bleeding time and clotting time were prolonged, the erythrocyte count, $\mathrm{Hb}$ concentration, and MCV values were decreased, and the $\mathrm{MCH}$ was increased, while the PCV, MCHC, total leucocytes count and the basophiles percentage did not showed any significant changes. The heterophiles and monocytes percentage were increased mean while the lymphocytic and eosinophil percentage were decreased during the study.
\end{abstract}

Key words: Lantana camara, hematology, rabbits.

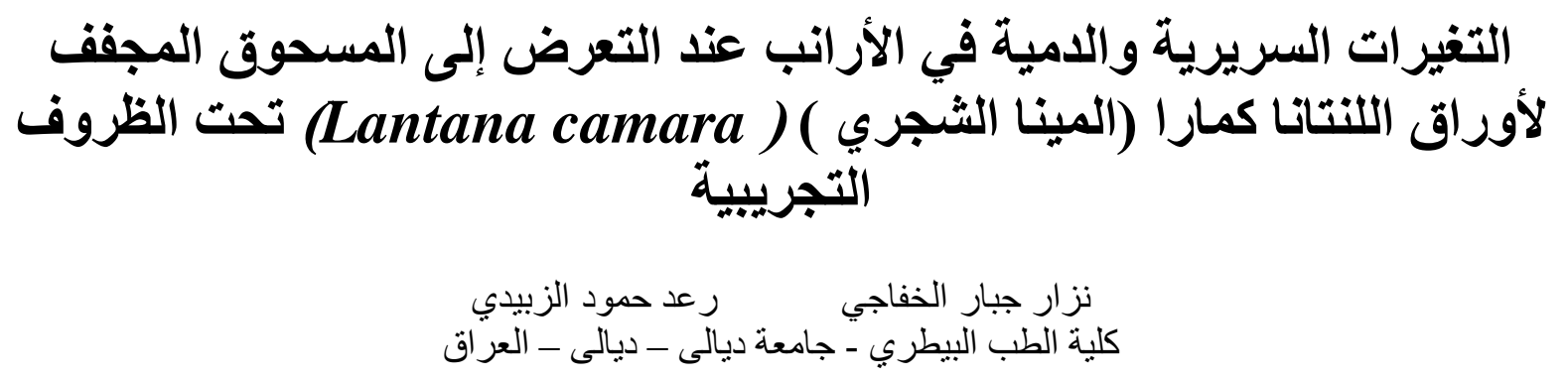

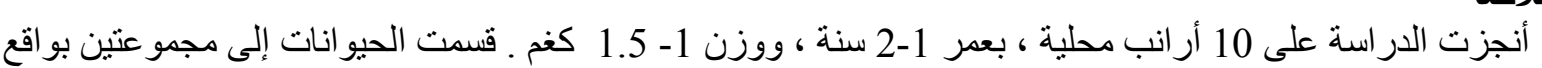

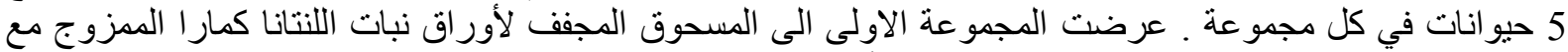

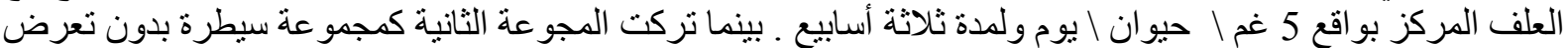

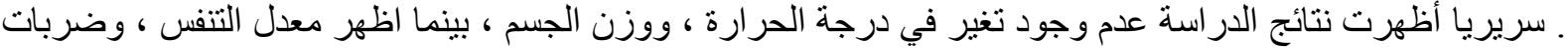

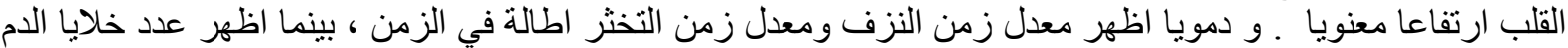

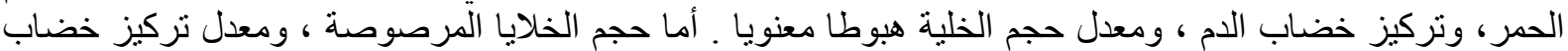

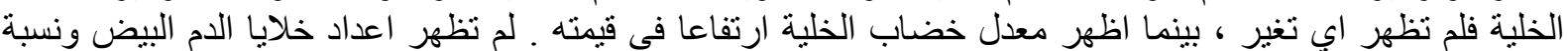

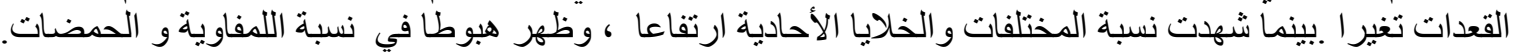

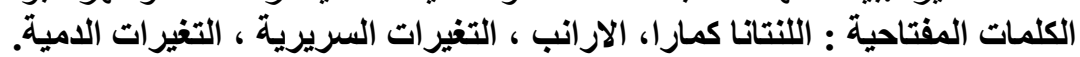

\section{Introduction}

Lantana is a natural plant from the pyrrolizidine alkaloids in the family of Verbenaceae. Parts of the plant when it is boiled can be used in tetanus treatment, rheumatism. Leaves are used as disinfectant for wounds, treatment of abrasions, and as lotion or fomentation for treatment of joints swelling (1). The principal active ingredient of lantana camara is triterpine acid (2-7). Lantana camara $L$.( Verbenaceae) is commonly known as the wide or red sage. It is the most widespread species in the genus 
lantana $(8,9)$. It is also listed as one of the most important medicinal plants around the world (10). The toxic dose depend upon the mode of induce the toxicity either through the exposure to leaves naturally or experimentally, in addition to formal of the plant (green, dry leaves or as extract). Sheep and cattle showed a signs of toxicity post exposure to the dry leaves in a doses of $(2,4$, $6,8,10$,12) gm / kg b.w. for 7- 18 days. Meanwhile laboratory animals showed a signs of toxicity post exposure to leave

\section{Materials and methods}

The study was conducted on 10 local breed rabbits 1-2 years of age, and $1-1.5 \mathrm{~kg}$ body weight. Rabbits were fed on concentrated food, and water giving ad libitum. They kept in room temperature (20$25{ }^{\circ} \mathrm{C}$ ), with half day light. Animals were divided into two equal groups. The exposed group receive the plant as powder form mixed with the food at a dose rate of $5 \mathrm{~g} / \mathrm{kg}$ b.w. daily for three weeks, while the other group left without exposure as a control group. The main parameters depended in the

\section{Results}

The body temperature, and body weight did not show any significant changes during the experiment. The respiratory rates was increased non significantly during the first week post exposure in comparison with preexposure values. While it is significantly increased in comparison with the control value in the same week at $\mathrm{P}<0,05$. During the second week post exposure to plant the respiratory rate was significantly decreased, which was significant at a level of $(\mathrm{P}<0.05)$ in comparison with the level in pre- exposure time. During the third week although it rise, but still lower than the level of pre-exposure time and not significantly differ than it, but it was significantly differ at the level of ( $\mathrm{P}<$ 0.05) in comparison with the level during the second week (Table 1). The heart rate decreased during the first week post exposure, which was significantly differ at a extract at a dose of $100-125 \mathrm{mg} / \mathrm{kg}$ b.w. $(11,12)$. Sharma et al., (13) describe the disease of rabbits resulted from giving different doses $(2,4,6 \mathrm{gm} / \mathrm{kg}$ b.w.) of extracted material of dry leaves $100-125$ $\mathrm{mg} / \mathrm{kg}$ b.w. post 4- 6 days. (14) referred to 0.5 and $1 \mathrm{gm} / \mathrm{kg}$ b.w. of dry leaves of Lantana camara did not cause toxicity in rabbits, while exposure to dry leaves at a dose of 2, 4, $6 \mathrm{gm} / \mathrm{kg}$ lead to occurrence of toxicity and appearance of clinical signs of toxicity.

study were included the clinical parameters (body temperature, heart rate, respiratory rate in addition to monitor the appetite, nature of feces, and any abnormal signs appear during the study). Hematologically the main parameters were, RBC, WBC, Hb, PCV, Red cell indices, bleeding time, clotting time according to (15). The results were analyzed statistically by the T test and LSD (the least significance, with a degree of $\mathrm{P}<0.05$ and $\mathrm{P}<0.01)$ according to (16).

level of $(\mathrm{P}<0.05)$ in comparison with the level of control group in the same week. During the second week post exposure to plant the heart rates increased, which was significant at $(\mathrm{P}<0.01)$ in comparison with the pre- exposure level, and the level in the first week post exposure. During the third week the heart rates increased to the maximum level, which was significantly differ at a level of $(\mathrm{P}<0.01)$ in comparison with the level in pre- exposure and the level during the first week post exposure to plant (Table 1). The bleeding time was prolonged during the first week post exposure to the plant, which was significantly differ at a level of $(\mathrm{P}<0.05)$ in comparison with the value of control group, and the level preexposure to plant during the third week more prolonged, and significantly differ at a level of $\mathrm{P}<0.05$ in comparison with the level in 
Table (1): The body temperature, respiratory rates, heart rates, and body weight of the control and treated groups.

\begin{tabular}{|c|c|c|c|c|c|}
\hline \multirow{2}{*}{ Parameters } & Groups & \multicolumn{5}{|c|}{ Weeks } \\
\cline { 3 - 6 } & 0 & 1 & 2 & 3 \\
\hline Body temp. C & Treated & $37.66 \pm 0.92$ & $37.3 \pm 0.45$ & $37.94 \pm 0.27$ & $38.36 \pm 0.38$ \\
\cline { 2 - 6 } & Control & $37.66 \pm 0.92$ & $37.85 \pm 0.32$ & $37.02 \pm 0.36$ & $37.17 \pm 0.18$ \\
\hline $\begin{array}{c}\text { Respiratory rate } \\
\text { minute }\end{array}$ & Treated & $139.5 \pm 8.27$ & $146.4 \pm 16.18 \mathrm{~A}^{* * *}$ & $102.8 \pm 18.10 \mathrm{a}^{*}$ & $157.2 \pm 12.35 \mathrm{c}^{*}$ \\
\cline { 2 - 6 } & Control & $139.5 \pm 8.27$ & $150 \pm 17.35$ & $141 \pm 8.10$ & $146.25 \pm 15.65$ \\
\hline $\begin{array}{c}\text { Heart rate beat } \\
\text { minute }\end{array}$ & Treated & $249 \pm 11.40$ & $208.8 \pm 27.19 \mathrm{~A}^{*}$ & $330 \pm 16.47 \mathrm{a}^{* *} \mathrm{~b}^{*}$ & $392 \pm 40.03 \mathrm{ab}^{* *}$ \\
\cline { 2 - 6 } & Control & $249 \pm 11.40$ & $271 \pm 14.36$ & $281.5 \pm 33.09$ & $282.5 \pm 41.70$ \\
\hline \begin{tabular}{c} 
Body weight / Kg \\
\cline { 2 - 6 }
\end{tabular} & Treated & $1.46 \pm 0.1$ & $1.40 \pm 0.07$ & $1.39 \pm 0.07$ & $1.38 \pm 0.08$ \\
\cline { 2 - 6 } & Control & $1.46 \pm 0.1$ & $1.46 \pm 0.18$ & $1.49 \pm 0.15$ & $1.47 \pm 0.12$ \\
\hline
\end{tabular}

The values are Mean \pm SE. a. means significance in comparison with 0 time of treated group, $b$. in comparison with $1^{\text {st }}$ week, c. in comparison with $2^{\text {nd }}$ week, A. significance in comparison with control group in the same week. * significance at $\mathbf{P}<0.05$, ** at $\mathrm{P}<0.01$.

Table (2): Bleeding time and clotting time of control and treated groups.

\begin{tabular}{|c|c|c|c|c|c|}
\hline \multirow[b]{2}{*}{ Parameters } & \multirow[b]{2}{*}{ Groups } & \multicolumn{4}{|c|}{ Weeks } \\
\hline & & 0 & 1 & 2 & 3 \\
\hline \multirow{2}{*}{$\begin{array}{c}\text { Bleeding time } \\
\text { Second }\end{array}$} & Treated & $21.8 \pm 6.74$ & $37 \pm 6.45 \mathrm{a} \mathrm{A}^{*}$ & $32 \pm 4.64$ & $41 \pm 5.35 \mathrm{aA}^{*}$ \\
\hline & Control & $21.8 \pm 6.74$ & $30 \pm 7.90$ & $25 \pm 6.12$ & $28.75 \pm 9.43$ \\
\hline \multirow{2}{*}{$\begin{array}{l}\text { Clotting time } \\
\text { Second }\end{array}$} & Treated & $40.7 \pm 9.16$ & $53 \pm 12.13$ & $55 \pm 10.39$ & $119 \pm 14.90 \mathrm{aA}^{*}$ \\
\hline & Control & $40.7 \pm 9.16$ & $18.75 \pm 2.39$ & $20.25 \pm 8.26$ & $21.75 \pm 13.90$ \\
\hline
\end{tabular}

The values are Mean \pm SE. a. means significance in comparison with 0 time of treated group, $b$. in comparison with $1^{\text {st }}$ week, c. in comparison with $2^{\text {nd }}$ week, A. significance in comparison with control group in the same week. * significance at $\mathbf{P}<0.05$, ** at $\mathbf{P}<0.01$.

pre- exposure time and control group at the same week (Table 2). There was no significant prolongation in the clotting time during the first and second weeks, but it become significantly different during the third week post exposure to plant with the value pre- exposure and with value of control group at the same week (Table 2). The erythrocyte count, hemoglobin values, packed cell volume, mean corpuscular hemoglobin concentration did not showed any significant changes during the experiment. During the second week the mean corpuscular hemoglobin was significantly decreased at a level of ( $\mathrm{P}<$ $0.05)$ in comparison with the level of first week post exposure. During the third week it increased, which was significantly differ in comparison with the level during the second week post exposure to plant and those of control group, at a level of $(\mathrm{P}<0.05)$. The mean cell volume during the third week increased significantly at level of $\mathrm{P}<0.05$ in comparison with control group at the same week (Table 3). The total leucocytes count did not significantly changed during the experiment. During the first week, the Heterophils percent was significantly decreased at a level of $(\mathrm{P}<0.05)$ in comparison with the pre- exposure value. During the second week post exposure it was increased, which was differ at a level of (P < $0.05)$ in comparison with the value during the first week post exposure to plant and control group value. During the third week post exposure it reached the maximum level, which was significant at a level of $(\mathrm{P}<0.05)$. in comparison with the level in pre- exposure time, and $(\mathrm{P}<0.01)$ in comparison with level during the first week post exposure, and value of the control group (Table 4). The lymphocytic percent non significantly increased in the first week post exposure to plant in comparison with the pre- exposure time level. During the second week post exposure to plant it decreased non significantly in comparison with the pre exposure time level, but differ at level of $\mathrm{P}<$ 0.05 in comparison with control group values. During the thirds week it decreased to 
Table (3): Total erythrocyte counts, Hb concentration, Packed cells volume, Mean cell volume, Mean cell hemoglobin, Mean cell Hemoglobin concentration of control and treated groups.

\begin{tabular}{|c|c|c|c|c|c|}
\hline \multirow[t]{2}{*}{ Parameters } & \multirow[t]{2}{*}{ Groups } & \multicolumn{4}{|c|}{ Weeks } \\
\hline & & 0 & 1 & 2 & 3 \\
\hline \multirow{2}{*}{$\begin{array}{c}\text { RBC } \\
\times 10^{6} / \mu 1 \\
\end{array}$} & Treated & $4.56 \pm 0.5$ & $4.26 \pm 0.25$ & $5.48 \pm 0.99$ & $3.91 \pm 0.24$ \\
\hline & Control & $4.56 \pm 0.5$ & $4.34 \pm 0.45$ & $4 \pm 0.34$ & $4.87 \pm 0.46$ \\
\hline \multirow{2}{*}{$\begin{array}{c}\mathrm{Hb} \\
\mathrm{g} / \mathrm{dl}\end{array}$} & Treated & $12.32 \pm 0.41$ & $12.37 \pm 0.39$ & $12.3 \pm 0.55$ & $11.78 \pm 0.56$ \\
\hline & Control & $12.32 \pm 0.41$ & $12.07 \pm 0.56$ & $12.25 \pm 0.67$ & $12.55 \pm 0.70$ \\
\hline \multirow{2}{*}{$\begin{array}{c}\text { PCV } \\
\%\end{array}$} & Treated & $35.4 \pm 1.95$ & $36.4 \pm 1.12$ & $36 \pm 1.64$ & $35 \pm 1.67$ \\
\hline & Control & $35.4 \pm 1.95$ & $35.5 \pm 1.55$ & $36 \pm 1.91$ & $34.75 \pm 0.75$ \\
\hline \multirow{2}{*}{$\begin{array}{c}\mathrm{MCV} \\
\mathrm{Fl} \\
\end{array}$} & Treated & $80.26 \pm 8.89$ & $85.94 \pm 2.95$ & $70.73 \pm 7.29$ & $89.73 \pm 2.85 \mathrm{~A}^{*}$ \\
\hline & Control & $80.26 \pm 8.89$ & $74.38 \pm 9.05$ & $76.36 \pm 13.14$ & $73.36 \pm 7.21$ \\
\hline \multirow{2}{*}{$\begin{array}{c}\mathrm{MCH} \\
\mathrm{Pg}\end{array}$} & Treated & $27.04 \pm 2.63$ & $29.1 \pm 1.07$ & $24.15 \pm 2.47 b^{*}$ & $30.19 \pm 0.90 \mathrm{Ac}^{*}$ \\
\hline & Control & $27.04 \pm 2.63$ & $28.70 \pm 3.12$ & $25.30 \pm 5.63$ & $26.24 \pm 1.97$ \\
\hline \multirow{2}{*}{$\begin{array}{c}\text { MCHC } \\
\mathrm{g} / \mathrm{dl}\end{array}$} & Treated & $35.31 \pm 1.71$ & $33.84 \pm 0.15$ & $34.16 \pm 0.09$ & $32.33 \pm 1.28$ \\
\hline & Control & $35.31 \pm 1.71$ & $34.68 \pm 0.66$ & $34.01 \pm 0.13$ & $36.15 \pm 2.166$ \\
\hline
\end{tabular}

The values are Mean \pm SE. a. means significance in comparison with 0 time of treated group, $b$. in comparison with $1^{\text {st }}$ week, $c$. in comparison with $2^{\text {nd }}$ week, A. significance in comparison with control group in the same week. * significance at $\mathrm{P}<0.05$, ** at $\mathrm{P}<0.01$.

Table (4): Total leucocytes count and differential leucocytes count of control and treated groups.

\begin{tabular}{|c|c|c|c|c|c|}
\hline Parameters & Groups & \multicolumn{4}{|c|}{ Week } \\
\cline { 3 - 6 } & & 0 & 1 & 2 & 3 \\
\hline \multirow{2}{*}{ WBC } & Treated & $4955 \pm 374.14$ & $5720 \pm 2.95$ & $5180 \pm 7.29$ & $4364 \pm 2.85$ \\
\cline { 2 - 6 } & Control & $4955 \pm 374.14$ & $5700 \pm 750.83$ & $5225 \pm 919.35$ & $5137.5 \pm 1191.70$ \\
\hline \multirow{2}{*}{$\mathrm{H} \%$} & Treated & $39 \pm 2.27$ & $35.2 \pm 1.07 \mathrm{a}^{*}$ & $52.6 \pm 2.47 \mathrm{Ab}^{*}$ & $56.6 \pm 0.90 \mathrm{a}^{*} \mathrm{bA}^{* *}$ \\
\cline { 2 - 6 } & Control & $39 \pm 2.27$ & $39.25 \pm 3.88$ & $34.25 \pm 4.02$ & $40.25 \pm 4.00$ \\
\hline \multirow{2}{*}{$\mathrm{L} \%$} & Treated & $54.9 \pm 1.10$ & $51.2 \pm 0.15$ & $46 \pm 0.09 \mathrm{~A}^{*}$ & $38.2 \pm 1.28 \mathrm{a}^{*} \mathrm{~A}^{* *}$ \\
\cline { 2 - 6 } & Control & $54.9 \pm 1.10$ & $42.75 \pm 4.98$ & $54 \pm 3.87$ & $45.75 \pm 3.19$ \\
\hline \multirow{2}{*}{$\mathrm{E} \%$} & Treated & $4.2 \pm 1$ & $8.2 \pm 3.20$ & $0.4 \pm 0.24 \mathrm{a}^{* *} \mathrm{~b}^{*}$ & $1.8 \pm 0.37 \mathrm{~b}^{*} \mathrm{c}^{* *}$ \\
\cline { 2 - 6 } & Control & $4.2 \pm 1$ & $5 \pm 0.70$ & $2 \pm 0.28$ & $3.25 \pm 0.47$ \\
\hline \multirow{2}{*}{$\mathrm{M} \%$} & Treated & $2.6 \pm 1.50$ & $3 \pm 4.43$ & $1.2 \pm 6.30 \mathrm{~b}^{*}$ & $3.4 \pm 3.36 \mathrm{a}^{*} \mathrm{~b}^{* *}$ \\
\cline { 2 - 6 } & Control & $2.6 \pm 1.50$ & $3.25 \pm 0.62$ & $1.25 \pm 0.25$ & $2.75 \pm 0.25$ \\
\hline \multirow{2}{*}{$\mathrm{B} \%$} & Treated & $0.4 \pm 2.03$ & $0.6 \pm 7.28$ & 0 & $0.6 \pm 3.82$ \\
\cline { 2 - 6 } & Control & $0.4 \pm 2.03$ & $0.75 \pm 0.47$ & 0 & 0 \\
\hline
\end{tabular}

The values are Mean \pm SE. a. means significance in comparison with 0 time of treated group, $b$. in comparison with $1^{\text {st }}$ week, $c$. in comparison with $2^{\text {nd }}$ week, A significance in comparison with control group in the same week. * significance at $\mathrm{P}<0.05$, ** at $\mathrm{P}<0.01$.

more lower levels, which was significant at level of $(\mathrm{P}<0.05)$ in comparison with preexposure time level, and with control group (Table 4). Eosinophil percent was not significantly increased during the first week. but significantly decreased in the second week post exposure to plant which was significant at a level of $(\mathrm{P}<0.01)$ in comparison with the pre- exposure time level, and at a level of $(\mathrm{P}<0.05)$ in comparison with the level of the first week post exposure to plant. During the third week post exposure it reached a level, which was significant at a level of $(\mathrm{P}<0.05)$ in comparison with the level in first week post exposure and $(\mathrm{P}<0.01)$ in comparison with the level of second week post exposure (Table 4). The monocytes percent increased during the third week post exposure to the level reached, which was significantly differ at a level of $(\mathrm{P}<0.05)$ in comparison with pre- exposure time level and a level of $(\mathrm{P}<$ 0.01 ) in comparison with the level in first week post exposure to plant (Table 4). The basophils percent did not showed any significant changes during the experiment. 


\section{Discussion}

The results of the study revealed no changes in body temperature. Researchers $(17,18,19)$ they refer to rise in body temperature in buffalo calves exposed to the plants. Increased in body temperature in rabbits, with increase in respiratory and heart rate and nonspecific fever $(18,19,20)$. The results of the study revealed increase in heart beats. $(17,21,22)$ referred to occurrence of necrosis in myocardium which indicate the direct toxic effect on heart tissues, patchy degeneration in myocardial fibers. (20) attribute the heart failure to these lesions. (21) confirm the direct effect of toxic material in leaves of lantana camara on heart tissue that leads to tachycardia. The results of the study revealed increase in respiratory rates, $(23,19)$ refer to increased respiratory and heart beat in poisoning due to hypoxia as a results of decreased in $\mathrm{RBC}$ count and $\mathrm{Hb}$. (22) observed pulmonary edema , congestion of blood vessels, alveoli, filled with pink color fluid homogenous fluid. alveoli dilatation, pulmonary emphysema, hydrothorax. $(23,19)$ refers to increased respiratory rate and heart rate to anemic anoxia Increased heart beat due to anemia in rabbits which leads to tachycardia and increase cardiac output and shorten circulation time that lead to cardiac hypertrophy $(24,2)$. The results of the study

\section{References}

1-Weenen H, Nkunya MH, Bray DH, Mwasumbi LB, Kinabo LS and Kilimali VA (1990) Antimalarial activity of Tanzanian medical; plants .Planto .Med. JH .56 : 368-370.

2-Seawright AA, and Hrdlicka J (1977) The oral toxicity for sheep of Triterpene acids isolated from Lantana camara .Aust Vet J ;53 : 230- 235.

3-Sharma OP (1984 a) Lantana camara toxicity ,control and utilization. Bio. Med. 9:204-209.

4-Sharma OP, Darwa RK, and Pattabhi V (1991a) Molecular structure polymorphism and toxicity of lantaden A, the pentacyclic triterpenoid from hepatoxic plant Lantana camara .J Biol.Toxicol;6: 57-63. revealed decreased, $\mathrm{RBC}$ counts, $\mathrm{Hb}$ concentration and $\mathrm{MCH}$, while $\mathrm{PCV}, \mathrm{MCHC}$ did not showed any changes. The values of MCV increased. $(25,26,27)$ refer to acute deficiency in RBC counts, $\mathrm{Hb}$, and platelets. (28) refer to slight decrease in $\mathrm{RBC}$, and $\mathrm{Hb}$. ( $28,22,29)$, refer to partial lysis of RBC due to toxicosis. ( $24,30,19)$ refer to anemia. $(18,26,27)$ refer to clear increase in PCV in sheep, cattle and buffaloes. (26) attribute this increase to hemoconcentration , and dehydration. (27) attributed this increase in PCV to the increase in decrease of body protein synthesis. The results of the study revealed bleeding time and clotting time prolongation. $(18,26,30)$ increased in bleeding and clotting time. increase in bleeding and clotting time. (27) increase in bleeding time in sheep attributed to decrease in prothrombin with decrease in protein synthesis and fibrinogen due to hepatic damage. The results of the study revealed WBC count not changes. Heterophils percentage increased. lymphocytes decreased, eosinophils decreased, monocytes increase, basophils not changes. $(26,27,30)$ refer to increase in WBC counts, neutrophils increase, lymphocytes decreased. (28) increase in total WBC. (25) slight increase in neutrophils.

5-Achhireddy N R, Singh M, Achhireddy L L, Nigg H $\mathrm{N}$, and Nagy $\mathrm{S}$ (1985) Isolation and partial characterization of phytotoxic compounds from Lantana camara . J Chem . Ecolo., 11 : 979 988.

6-Sharma O P, Darwa RK, and Ramesh D (1990) Atriterpenoid acid, lantanen D from Lantana camara .Ind Vet Res ; $29: 3961$.

7-Sharma O P, Vaid J, and Sharma PD (1991b) Comparison of lantadens content and toxicity of different taxa of the lantana plant. Ind J Res ; 17 : 2283.

8-Sharma OP, Darwa R.K, Krishna L, and Makker HPS (1988) Toxicity of Lantana camara leaves 
and isolated toxins to rabbits. Vet Hum . Toxicol; $30: 214-218$.

9-Ghisalberti EL (2000) Lantana camara L Verbenaceae ) Fitoterapiua ; $71: 467-486$.

10- Ross IA (1999) Medicinal Plants of the World .Chemical Constituents. Traditional and Modern Medical Uses. Humana Press, New Jersey : 487.

11-Sastry MS, and Singh Y P (1979) Experimental Lantana poisoning and its treatment in livestock. Ind. Vet. J. 40: $78-82$.

12-Mauriyal MM and Gupta I (1983) Study of experimental Lantana camara poisoning in sheep with particular reference to biochemical changes in blood. J. Vet . Res. 6: 38- 41.

13-Sharma OP, Makkar HP and Darula RK (1988c) A review of the noxious plant Lantana camara. Toxicon .26:972. 987.

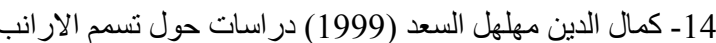

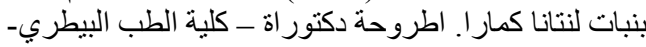

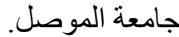

15-Coles EH (1986) Veterinary Clinical Pathology. $4^{\text {th }}$ ed. W.B. Saunders Co. Philadelphia: 20, 98, 102.

16-Steel R G and Torrie J H (1985) Principles and procedures of statistics, a Biometrical approach, $2^{\text {nd }}$ ed., McGraw - Hill, Inc., Singapore: 183 .

17-Sliva FM, and Couto ES (1971) Experimental Lantana camara poisoning in cattle in the state of Pernambuco, Brazil. Vet Bull.1973, Vol 31 No 218, abst. No : 1770.

18-Dhillon KS, and Paul BS (1971) Clinical studies of Lantana camara poisoning in buffalo calves, with special reference to its effect on rumen motility .Ind J Anim Sci.41: 945

19-Hari R, Shivanani GA and Joshi HC(1973) Therapeutic efficacy in Lantana poisoning in Buffalo calves in relation to clinical and hematological studies. Ind. Vet J. 50: 764- 770.
20-Jubb KVF, and Kennedy PG (1970) Pathology of domestic animals. $2^{\text {nd }}$ ed. London : 224 .

21-Seawright AA, and Allen JG (1972) pathology of the liver and kidney in lantana poisoning of cattle. Aust Vet J ; $48: 323-330$.

22-Sharma OP, Makkar H P S, Darwa R K and Negi S S (1981a) A review of the toxicity of Lantana camara in animals. Clini Toxicol ; 18: 1077. 42 .

23-Seawright A A (1963 a) Cobalt in effective against experimental Lantana poisoning. Aust Vet J . ; 39 : 249-250 .

24-Seawright AA (1964) Studies on the pathology of experimental Lantana camara poisoning of sheep .Path Vet. 1 : 504 -529. 22.

25-Seawright AA (1963b) Studies on experimental intoxication of sheep with Lantana camara. Aust. Vet J ; 39 : 340- 344.

26-Sharma OP, Makkar HPS, Pal RN, and Negi SS (1981b) Fragility of erythrocytes in animals affected by Lantana poisoning. Clinic. Toxicol. 18 : 25- 35 .

27-Uppal R P, and Paul B S (1982) Hematological changes in experimental lantana poisoning in sheep. Ind Vet J ; 59 : 18-24.

28-Dwivedi SK, Shivnami GA and Joshi H (1970) Clinical and biochemical studies in Lantana camara poisoning in ruminants. Ind. J Anim. Sci. 41: 948-953.

29- Gopinath C, and Ford E J H (1969) The effect of Lantana camara on the liver of sheep. J Path. 99: 75- 85.

30-Kalra DS, Dixit SN, Vrerma PC and Dwivedi P (1984) Studies on experimental Lantana poisoning in buffalo calves with special reference to its Pathology and histochemistry. Haryana Vet. 23: 98-105. 